\title{
CONTRACTUAL RELATIONS IN THE NEW ECONOMIC COMPETITION STRATEGIES OF TNCS
}

\author{
Tetiana Melnik', Liudmyla Kudyrko², Liliia Samsonova ${ }^{3}$
}

\begin{abstract}
The purpose of the paper is to summarize theoretical studies in the field of contractual relations implementation in the modern strategies of TNCs economic competition on international product and resource markets, as well as to assess the impact of certain contractual relations types on the macroeconomic dynamics of countries integrated into the global value chains of TNCs. Methodology. Based on the World Bank Open Data and UNCTADSTAT, there was made the assessment of indirect socio-economic and innovative effects of contract production on the macroeconomic indicators of the individual countries development by means of the correlationregression method. Results. The influence of institutional, political, and economic restrictions that restrain the investment activity of international corporations on the international markets of finished and intermediate products is disclosed. A trend that complicates the forms and methods of external expansion in terms of more flexible latent forms, in particular, through contractual relations (subordinate production, licensing, franchising, contract management) is identified. The role of international contractual relations in measuring nonlinear formats of the externalization of TNC business is revealed. Exogenous (related to the institutional environment of the host-countries) and endogenous factors (the sphere of activity, corporate strategy, formed competencies and competitive advantages of the companies) that allow TNCs to obtain competitive advantages from the use of contractual relations in multi-level network structures with coordination mechanisms and management regimes are determined. Practical implications consist in the improvement of a theoretical and methodical approach to assessing international contractual relationships from the positions of microeconomic analysis (means TNC's management strategies) and taking into account macroeconomic effects (means their influence on the macroeconomic development of the contracting and implementing parties is proposed). Value/originality. The article points on problems of expanding the practice of international contractual relations: optimization of taxation, predatory exploitation of human, technological and natural resources of host countries by TNCs, "freezing" of national subcontractors on the stages with low value added, distortion of export capabilities of host countries by products export imitation created by means of the foreign suppliers' give-and-take raw materials and, as a result, the distortion of the balance of payments.
\end{abstract}

Key words: international contractual relations, contract manufacturing, transnational companies, economic competition, international management.

JEL Classification: F01, F02, F14, F23

\section{Introduction}

The intensification of economic rivalry between the subjects of the global economy for not only goods but also resources of international markets leads to the search for answers to new challenges of international production and distribution management, and first of all, for transnational companies (TNCs). In the last decade, the traditional format of foreign expansion through investment has begun to be complemented by more flexible, latent forms of external expansion. International companies are increasingly using the methods of organizing their own international production, which is an alternative to direct investment and are determined by UNCTAD experts as an activity that is not mediated by the investment flow and is not related to the equity nature of the interaction. Such a new

\footnotetext{
Corresponding author:

${ }^{1}$ Kyiv National University of Trade and Economics, Ukraine.

E-mail: melnikknteu998@gmail.com

ORCID: http://orcid.org/0000-0002-3839-6018

${ }^{2}$ Kyiv National University of Trade and Economics, Ukraine.

E-mail: 1.kudirko@ukr.net

${ }^{3}$ Kyiv National University of Trade and Economics, Ukraine.

E-mail: samsonova.lilija.gov.ua@ukr.net
} 
format of foreign expansion implies a contractual form of market transactions between companies of homecountries (usually TNCs from developed countries) and companies of host countries (usually small and medium enterprises from developing countries and countries with transitional economies).

The sales under contractual relations as of 2015 exceeded 2 trillion USD and captured about $10 \%$ of global exports (UNCTAD, 2011). Now contractual relations are an integral complex system of global TNCs' supply chains management and are actively supported by the governments of the host-countries with the aim to increase localization of international production on their territory and integrate the national business into the system of global value-added chains. At the same time, international practice demonstrates the extremely controversial impact of contractual relations on the country development of both executing countries and countries of origin, considering its socio-economic and innovation risks. In the mentioned conditions, the actual scientific and practical task is to reveal the peculiarities of TNCs' economic rivalry strategies modernization through contractual relations and to assess the macroeconomic effects of their development.

\section{Unsolved issues that are a part of the overall problem}

The problem of the factors and mechanisms of the TNCs activities externalization within their global production systems with the participation both affiliated andindependent companies was disclosed in the works of S. Barrientos, J. Gereffi, and A. Rossi (Barrientos, 2011). In the studies of Peter J. Buckley and Mark C. Casson, it was made a comparison of the advantages and risks of internationalization and externalization of international companies (Buckley\& Casson, 2009). In the studies of $S$. Dinc and I. Erel, there were assessed expenditures on cross-border activities internationalization, including multivariate and multicurrency operations, which are increasing along with the strengthening of sociocultural and political differences between countries (Dinc \& Erel, 2012). The generalized results of empirical studies dedicated to the assessment of the macroeconomic effects created by countries' inclusion in the global value chains through contractual relation are presented in the works of S. Miroudot, R. Lanz, and A. Ragoussis (Miroudot \& Lanz, 2009). Sectoral peculiarities of the international business development through modern contractual forms are disclosed in the works of G. Duhinets (Duhinets, 2016), A. Mazaraki, S. Melnichenko (Mazaraki, 2018), O. Rohach (Rohach, 2013) The estimation of the potential growth of global production and distribution networks was carried out in R. Baldwin's works (Baldwin, 2013).

The majority of scientific publications consider the problems of TNCs' economic rivalry in terms of modifying investment formats, and the development of cross-border contractual relations is identified as a minor thing and not relevant to important issues for national economic development. At the same time, the statistics of international organizations and national statistical services confirm an increase in operations amount under international contracts and other types of crossborder contractual agreements. Moreover, a number of problems associated with the latent optimization of TNC fiscal payments through various types of international contractual operations (franchising, licensing, contract management), and the predatory exploitation of host country resources without providing investment resources support; "freezing" national subcontractors at low value-added production stages; distortion of the country export opportunities and the suchlike are becoming barefaced. Therefore, issues related to the analysis of the contractual relations place and its role in the TNCs' economic rivalry strategies modernization and the assessment of macroeconomic effects from the national open economies incorporation into global reproduction processes through the contractual relations require in-depth analysis.

\section{Approaches to TNCs' global networks management}

The global business environment of the first decade of the XXI century is characterized by the transformation of an organization established forms of production, trade and logistics companies from linear hierarchical structures to network structures, which leads to the formation of global cooperation networks. Therefore, more and more countries and regions of the world with varying intensity are becoming participants in the global reproduction system. The objective basis for strengthening international cooperation is the fundamental changes in the driving forces of the international labour division.

At the end of the twentieth century, the term "new international labour division" is being introduced by researchers with an emphasis not so much on the macro level as on the micro level, on the features of the global TNC production strategy. In the context of globalization shifts, transnational companies optimize the distribution of production operations in countries that ensure the resources optimization from the crossborder allocation.

The post-industrial stage of development, at which the developed countries are characterized, is marked out by deepening, variability, and complication of production and commercial interrelations at both national and international levels. First of all, it applies to TNC; therefore, in the conditions of transformation of the organizational, economic, and technological background, there is a need to improve their development strategies. 
It is complicated to identify the role of contractual relations in the TNCs modern strategies and the mechanisms of their influence on international cooperation. After all, the "channels" of social and economic ties and the separation of powers (Hodgson, 1988; Derevynskyi, 2011) between the levels and components of the TNC network, and not only within the corporate systems, in particular, by the J. Hodgson's definition, become not just "bundles" of property rights but also control over information, management and planning relations, complex "pyramid" of internal and external financial control, administrative and other noneconomic regulation, personal union, psychological and cultural climate, and even ideology of the company; market relations (for example, transfer prices) within these sophisticated complexes play a subordinate rather than a key role.

These processes and relations can no longer be described as exclusively intra-company relations or management itself: within and around them exists a complex of economic (resource allocation, income and property relations, reproduction proportions, organization and motivation of labour), social (intracorporate "classes", lifestyle, values, interpersonal relations and relations between social groups, stratification) and forceful relations, which constitute one of the key aspects of real socio-economic life of the modern world (Belousov, 2012).

New formats of cross-border relations are increasingly acquiring a resilience nature, are distinguished by a certain hierarchy and focus, which allows identifying them as a system of international cooperation. Considering the transformations that occur in international business, it will be logical to recognize TNCs not just a company with many branches abroad but a full-fledged economy, which has a significant impact on the development of economic relations in the world. The research vector of the international cooperation system is shifting precisely to the plane of TNC activity, and the concept of production and distribution cooperation is closely intertwined with global production networks. This statement was also reflected in the works of R. Kashbrasiyev, who reveals this aspect of global production networks as a modern form of international cooperation based on competition (Kashbrazyev, 2017).

Global production networks in terms of cooperation issues are sequential chains or complex networks that have been formed due to the production processes fragmentation and division of production operations (and/or business functions) between different countries, both on the basis of direct ownership and in the form of contractual relations.

TNCs manage global production networks through a complex system of relationships with suppliers and various forms of administration. Now TNCs are increasingly differentiating their activities within the production network, placing individual processes in the most favourable locations, both in the home region and abroad. It is inherent for companies with a significantly fragmented organizational structure or configuration of global production networks. It may include multiple operations and tasks; numerous affiliates, contract partners and trade or a combination of these forms. The managerial component also concerns the geography of the operations distribution, production spheres, and forms of cooperation (Babek, 2015).

In such global production networks, TNCs should manage the fragmented, geographically dispersed production process, trade and investment flows, while at the same time ensuring that these actions are fully consistent with the company's strategic goals (UNCTAD, 2011).

Based on the generalization of the leading TNCs practices, scientists S. Altomonte and A. Rungiemphasize on the fact that they coordinate global production networks using complex coordination mechanisms between suppliers and various management modes: from direct ownership of foreign assets to contractual relationships (in the case of international production, not related to equity) and trade. These management regimes and hierarchical structures in the global production networks through which they manifest, significantly affect the distribution of economic benefits and long-term incentives for development (Altomonte, 2013). The TNCs decision on where to invest and with whom to maintain a partnership, based on the factors of global production networks location, depends on the segment, goals or the specifics of TNC activities.

\section{Assessment of TNCs' contractual relations influence}

Considering to the point of contractual relations in the newest management strategies of TNCs from the view of micro-level would be incomplete if we did not pay attention to the macroeconomic dimension of their implementation at the country level integrated into the system of international cooperation through contractual relations. Of course, the interests of contractors at the level of performers and customers differ. In particular, for the home-countries, it is about minimizing production costs, access to unique production and technological resources, overcoming trade barriers. Also, companies from developed countries can use the contractual mechanism to optimize (both in money and in time) in the process of building their international value chains and then spreading the range of external expansion. On the other hand, developing countries use contractual relationships to include their business in the value chains; others use them for the purpose of technical and technological improvement of production processes and the subsequent creation of their own product, brand or trademark. 
For a number of countries in the context of ultra-high political risks, including restrictions on the investment activities of non-resident companies, contractual relationships serve as the determining mechanism for the inclusion of individual sectors of the economy in international trade. These countries mainly embrace transitive economies, some of the developing countries, countries in the African and Asian regions, and a group of Latin American countries.

Considering the fact that international contractual relations are the relatively new and complex object of research both in accounting and identification methodology, empirical work of both domestic and foreign scientists regarding them has a rather selective manifestation. Nowadays, statistics on world trade and production volumes, mediated by contractual relations, is incomplete, moreover due to their impact on national and global economic development.

We propose to evaluate their indirect effects (socio-economic and innovative) on the macroeconomic indicators of individual countries and draw conclusions about their significance. Next section shows the results of the calculation of correlation indicators describing the nature and intensity of the relationship between contractual relations and socio-economic and innovation processes in the countries.

\section{The results of the calculation}

For calculations, there were used the statistical databases World Bank Open Data and UNCTADSTAT (World Bank; UNCTAD). Indicators that directly or indirectly characterize socioeconomic and innovative processes, in particular, are the following socioeconomic: GDP per capita (USD), unemployment rate (Unemp, \% of people of working age), the level of economy openness ( $\mathrm{EcOp}$, the share of exports in GDP in \%), foreign direct investment inflows (FDI, USD million) and innovative ones: exports of lowskilled and technologically intensive production (LS\&TI, thousand USD), exports of labour-intensive and resource-intensive production (LI\&RI, thousand USD), export of modern technology and technologyintensive production (MT\&TI, thousand USD), exports of highly qualified and technologically intensive production (HQ\&TI, thousand USD). According to available statistical data, the correlation coefficients were calculated for contractual production (export and import flows) for 2005-2016. Table 1 shows the correlation between exports of contract production services and indicators of socio-economic and innovation development of individual economies. Table 2 presents the correlation between imports of contract manufacturing services and indicators of socioeconomic and innovation development of individual countries.
In the case of contract manufacturing services import (Table 2), we note that the number of countries in which international organizations provide statistical data is much smaller.

\section{Description of results mentioned in Table 1}

The data in Table 1 show that the export of contract manufacturing services with different sighs affects the GDP per capita for the different countries. The negative impact on the growth of this indicator can be explained by the fact that the added value created during the processing of tolling raw materials is exported abroad and stays in the home country. This condition of affairs may indicate that in countries with a negative relationship between the indicators, almost all finished products produced on the basis of toll-free raw materials are returned to customers and do not consume it in the national market. In addition, in many countries of the world, services on the processing of toll-free raw materials are subject to preferential tax treatment, where the VAT itself is exempted for the finished products and the cost of processing services. In other words, releasing this type of activity from VAT and increasing its exports, countries are facing the situation of value-added outflow abroad, which, in turn, negatively affects the economic growth of the exporting country. Countries with is a negative interdependence are: Armenia, Australia, Bangladesh, Belarus, Belize, Bolivia, Macao (China), Costa Rica, Czech Republic, Denmark, Dominican Republic, Estonia, Fiji, Greece, Iceland, Republic of Ireland, Romania, Samoa, Palestine. It is important to note that despite the fact that countries with a different level of development have been affected by the negative relationship between exports of contracted production services and the GDP per capita, however, for developed countries, its significance is small - from 0.01 to 0.11 ; another situation for developing countries - an average is 70 cases out of 100 .

In the case where there is a positive and significant relationship between the previously mentioned indicators, it can be argued that: first, the country sells a part of the produced products in the domestic market; and secondly, countries take over the technology of production and, within building up of production potential, already create their own goods; thirdly, this type of activity is appropriately taxed and contributes to the country budget; fourthly, the use of contract production launches the work of complementary and linked industries which produce value added in the country. Significant influence is observed for the following countries: Albania, Belgium, Bosnia and Herzegovina, Croatia, Germany, Honduras, Italy, Korea, Malaysia, Nicaragua, Poland, Moldova, Serbia, Slovakia, Slovenia, Switzerland, Macedonia, and Ukraine.

For a significant number of countries, the export of contract manufacturing services has a positive impact 
Table 1

Correlation between exports of contract production services and indicators of socio-economic and innovation development of individual economies

\begin{tabular}{|c|c|c|c|c|c|c|c|c|c|}
\hline № & Individual economies & GDP per capita & Unemp & LS\&TI & LI\&RI & MT\&TI & HQ\&TI & FDI & $\mathrm{EcOp}$ \\
\hline 1 & Albania & 0,74 & 0,25 & 0,46 & $-0,01$ & 0,06 & $-0,22$ & 0,51 & $-0,14$ \\
\hline 2 & Armenia & $-0,73$ & $-0,05$ & 0,72 & $-0,54$ & $-0,22$ & $-0,01$ & $-0,68$ & 0,81 \\
\hline 3 & Australia & $-0,01$ & 0,03 & $-0,36$ & $-0,29$ & $-0,33$ & 0,28 & 0,26 & $-0,10$ \\
\hline 4 & Austria & 0,49 & 0,10 & $-0,08$ & $-0,15$ & 0,18 & 0,56 & $-0,56$ & 0,59 \\
\hline 5 & Azerbaijan & 0,19 & 0,05 & 0,59 & $-0,36$ & 0,51 & 0,76 & 0,74 & $-0,46$ \\
\hline 6 & Bangladesh & $-0,64$ & $-0,37$ & $-0,21$ & 0,27 & 0,73 & 0,52 & 0,92 & 0,49 \\
\hline 7 & Belarus & $-0,05$ & 0,35 & 0,02 & $-0,34$ & $-0,32$ & 0,05 & $-0,03$ & 0,04 \\
\hline 8 & Belgium & 0,73 & $-0,34$ & $-0,01$ & $-0,34$ & $-0,06$ & 0,27 & $-0,54$ & 0,82 \\
\hline 9 & Belize & $-0,75$ & $-0,33$ & 0,21 & $-0,35$ & $-0,26$ & $-0,43$ & $-0,20$ & $-0,23$ \\
\hline 10 & Bermuda & 0,07 & $\mathrm{H} / \mathrm{A}$ & $-0,14$ & $-0,41$ & 0,13 & 0,26 & $-0,13$ & 0,10 \\
\hline 11 & Bolivia & $-0,80$ & 0,26 & $-0,58$ & 0,20 & $-0,30$ & 0,45 & 0,35 & $-0,08$ \\
\hline 12 & Bosnia and Herzegovina & 0,86 & 0,02 & 0,36 & $-0,10$ & 0,54 & 0,73 & $-0,46$ & 0,08 \\
\hline 13 & Bulgaria & 0,15 & $-0,72$ & 0,20 & $-0,15$ & 0,50 & 0,62 & $-0,56$ & 0,71 \\
\hline 14 & Burkina Faso & 0,70 & 0,16 & $-0,27$ & $-0,01$ & 0,53 & 0,39 & 0,71 & 0,27 \\
\hline 15 & Cape Verde & 0,23 & $-0,73$ & $-0,13$ & 0,34 & 0,16 & 0,75 & $-0,38$ & $-0,54$ \\
\hline 16 & China & 0,42 & 0,39 & $-0,14$ & $-0,43$ & $-0,77$ & $-0,82$ & $-0,83$ & 0,76 \\
\hline 17 & China, Macao SAR & $-0,79$ & 0,83 & $-0,18$ & $-0,19$ & $-0,04$ & 0,62 & 0,56 & $-0,57$ \\
\hline 18 & Costa Rica & $-0,14$ & 0,21 & 0,04 & 0,91 & 0,84 & $-0,15$ & 0,81 & $-0,75$ \\
\hline 19 & Cote d'Ivoire & $-0,49$ & $-0,37$ & 0,09 & $-0,18$ & 0,68 & $-0,08$ & 0,63 & $-0,75$ \\
\hline 20 & Croatia & 0,60 & $-0,80$ & 0,39 & $-0,43$ & 0,65 & 0,73 & $-0,52$ & 0,62 \\
\hline 21 & Cyprus & 0,16 & 0,47 & 0,25 & $-0,41$ & 0,08 & 0,51 & 0,22 & 0,65 \\
\hline 22 & Czech Republic & $-0,22$ & $-0,57$ & 0,43 & 0,06 & 0,65 & 0,45 & $-0,36$ & 0,95 \\
\hline 23 & Denmark & $-0,08$ & $-0,04$ & $-0,16$ & $-0,49$ & 0,22 & 0,01 & $-0,16$ & 0,63 \\
\hline 24 & Dominican Republic & $-0,91$ & $-0,62$ & 0,22 & $-0,11$ & 0,25 & 0,84 & 0,39 & $-0,46$ \\
\hline 25 & El Salvador & 0,22 & 0,17 & 0,44 & 0,27 & 0,77 & 0,07 & $-0,20$ & $-0,17$ \\
\hline 26 & Estonia & $-0,16$ & $-0,66$ & $-0,10$ & $-0,28$ & 0,25 & 0,53 & $-0,77$ & 0,83 \\
\hline 27 & Fiji & $-0,47$ & $-0,82$ & 0,01 & 0,13 & 0,67 & 0,68 & $-0,06$ & $-0,14$ \\
\hline 28 & Finland & 0,49 & $-0,76$ & $-0,29$ & $-0,50$ & $-0,37$ & $-0,68$ & 0,02 & $-0,33$ \\
\hline 29 & France & 0,34 & 0,68 & 0,03 & $-0,54$ & $-0,38$ & 0,47 & $-0,23$ & 0,86 \\
\hline 30 & Georgia & $\mathrm{H} / \mathrm{A}$ & $-0,53$ & 0,21 & $-0,12$ & 0,05 & 0,65 & 0,47 & 0,92 \\
\hline 31 & Germany & 0,52 & $-0,22$ & $-0,06$ & $-0,16$ & 0,32 & 0,48 & $-0,61$ & 0,81 \\
\hline 32 & Greece & $-0,01$ & $-0,33$ & $-0,38$ & $-0,46$ & $-0,16$ & 0,26 & $-0,03$ & 0,84 \\
\hline 33 & Honduras & 0,79 & 0,88 & 0,21 & 0,81 & 0,67 & 0,80 & 0,57 & $-0,80$ \\
\hline 34 & Hungary & 0,18 & $-0,28$ & 0,31 & 0,20 & 0,77 & $-0,30$ & $-0,42$ & 0,77 \\
\hline 35 & Iceland & $-0,11$ & 0,28 & $-0,34$ & $-0,05$ & 0,03 & $-0,56$ & $-0,43$ & 0,81 \\
\hline 36 & Ireland & $-0,08$ & 0,78 & 0,28 & 0,51 & 0,04 & 0,22 & 0,60 & 0,81 \\
\hline 37 & Italy & 0,76 & $-0,68$ & $-0,14$ & $-0,41$ & 0,11 & 0,54 & $-0,10$ & 0,67 \\
\hline 38 & Japan & 0,54 & $\mathrm{H} / \mathrm{A}$ & $-0,11$ & $-0,55$ & $-0,17$ & $-0,68$ & $-0,13$ & 0,51 \\
\hline 39 & Republic of Korea & 0,88 & $-0,33$ & 0,37 & 0,24 & $-0,35$ & $-0,54$ & 0,16 & $-0,38$ \\
\hline 40 & Latvia & 0,02 & $-0,82$ & 0,11 & $-0,30$ & 0,41 & 0,79 & $-0,35$ & 0,87 \\
\hline 41 & Lebanon & 0,14 & 0,30 & $-0,38$ & $-0,39$ & $-0,11$ & $-0,02$ & $-0,77$ & $-0,76$ \\
\hline 42 & Lithuania & 0,11 & $-0,54$ & 0,22 & 0,14 & 0,40 & 0,64 & $-0,59$ & 0,90 \\
\hline 43 & Luxembourg & 0,35 & $-0,63$ & $-0,47$ & $-0,56$ & $-0,41$ & $-0,60$ & 0,19 & 0,76 \\
\hline 44 & Malaysia & 0,88 & 0,49 & 0,50 & 0,17 & 0,61 & 0,34 & 0,55 & $-0,83$ \\
\hline 45 & Morocco & 0,17 & 0,57 & $-0,15$ & $-0,29$ & 0,14 & $-0,14$ & 0,49 & 0,32 \\
\hline 46 & Myanmar & 0,39 & $-0,33$ & 0,13 & $-0,17$ & 0,10 & 0,31 & 0,02 & 0,47 \\
\hline 47 & Nicaragua & 0,95 & $\mathrm{H} / \mathrm{A}$ & 0,79 & $-0,17$ & 0,86 & $-0,51$ & 0,80 & 0,66 \\
\hline 48 & Paraguay & 0,49 & $-0,48$ & 0,12 & 0,47 & 0,80 & 0,56 & 0,20 & $-0,87$ \\
\hline 49 & Poland & 0,58 & $-0,17$ & 0,72 & 0,42 & 0,70 & 0,77 & $-0,19$ & 0,93 \\
\hline 50 & Portugal & 0,06 & 0,16 & 0,19 & 0,08 & 0,35 & 0,37 & 0,16 & 0,89 \\
\hline 51 & Republic of Moldova & 0,94 & $-0,73$ & 0,33 & $-0,51$ & 0,50 & 0,53 & $-0,45$ & $-0,51$ \\
\hline 52 & Romania & $-0,55$ & $-0,54$ & 0,19 & $-0,37$ & 0,68 & 0,30 & $-0,45$ & 0,73 \\
\hline 53 & Russian Federation & 0,46 & $-0,12$ & $-0,04$ & $-0,56$ & 0,20 & 0,32 & $-0,30$ & $-0,69$ \\
\hline 54 & Samoa & $-0,56$ & $-0,03$ & $-0,03$ & $-0,28$ & $-0,62$ & 0,24 & 0,13 & $-0,47$ \\
\hline 55 & Serbia & 0,98 & $-0,34$ & 0,38 & 0,15 & $-0,61$ & 0,27 & 0,12 & 0,79 \\
\hline 56 & Slovakia & 0,90 & $-0,05$ & 0,15 & $-0,11$ & 0,60 & 0,47 & $-0,71$ & 0,84 \\
\hline 57 & Slovenia & 0,73 & $-0,35$ & 0,41 & 0,13 & 0,53 & 0,69 & 0,28 & 0,82 \\
\hline 58 & The State of Palestine & $-0,46$ & $\mathrm{H} / \mathrm{A}$ & 0,38 & 0,56 & 0,72 & 0,36 & 0,08 & $\mathrm{H} / \mathrm{A}$ \\
\hline 59 & Switzerland & 0,85 & 0,59 & $-0,28$ & 0,07 & 0,01 & 0,73 & $-0,15$ & 0,67 \\
\hline 60 & Tajikistan & 0,49 & $-0,22$ & 0,35 & $-0,24$ & 0,28 & 0,56 & 0,29 & $-0,63$ \\
\hline 61 & Macedonia & 0,80 & $-0,69$ & 0,02 & $-0,35$ & 0,95 & 0,85 & $-0,25$ & 0,71 \\
\hline 62 & Ukraine & 0,81 & $-0,17$ & 0,19 & $-0,37$ & $-0,40$ & $-0,61$ & $-0,57$ & 0,14 \\
\hline 63 & United Kingdom & 0,07 & 0,59 & 0,22 & $-0,50$ & 0,42 & 0,17 & $-0,28$ & 0,74 \\
\hline
\end{tabular}


Table 2

Correlation between imports of contract manufacturing services and indicators of socio-economic and innovation development of individual countries

\begin{tabular}{|c|c|c|c|c|c|c|c|c|c|}
\hline № & Individual economies & GDP per capita & Unemp & LS\&TI & LI\&RI & MT\&TI & HQ\&TI & FDI & $\mathrm{EcOp}$ \\
\hline 1 & Austria & 0,55 & 0,51 & $-0,27$ & 0,06 & 0,26 & 0,65 & $-0,46$ & 0,60 \\
\hline 2 & Belgium & 0,46 & $-0,08$ & $-0,30$ & $-0,32$ & 0,18 & 0,36 & $-0,38$ & 0,78 \\
\hline 3 & Bulgaria & 0,03 & $-0,51$ & 0,16 & $-0,18$ & 0,74 & 0,77 & $-0,62$ & 0,63 \\
\hline 4 & Burkina Faso & 0,75 & $-0,13$ & $-0,42$ & 0,21 & 0,53 & 0,37 & 0,69 & 0,27 \\
\hline 5 & China & 0,84 & 0,43 & 0,49 & 0,54 & 0,77 & 0,78 & 0,82 & $-0,83$ \\
\hline 6 & China, Macao & $-0,79$ & $-0,27$ & $-0,24$ & $-0,22$ & $-0,11$ & 0,59 & 0,39 & $-0,63$ \\
\hline 7 & Croatia & 0,35 & $-0,02$ & 0,51 & $-0,57$ & 0,70 & 0,65 & $-0,56$ & 0,40 \\
\hline 8 & Czech Republic & 0,39 & $-0,56$ & 0,44 & 0,19 & 0,72 & 0,54 & $-0,43$ & 0,89 \\
\hline 9 & Denmark & 0,16 & 0,09 & $-0,33$ & $-0,42$ & 0,29 & $-0,01$ & 0,04 & 0,52 \\
\hline 10 & Estonia & 0,87 & $-0,17$ & $-0,20$ & $-0,20$ & 0,39 & 0,71 & $-0,80$ & 0,87 \\
\hline 11 & Finland & 0,22 & 0,30 & $-0,68$ & $-0,60$ & $-0,38$ & $-0,77$ & $-0,01$ & $-0,37$ \\
\hline 12 & France & 0,17 & 0,48 & $-0,19$ & $-0,57$ & $-0,38$ & 0,61 & $-0,26$ & 0,78 \\
\hline 13 & Georgia & $-0,04$ & $-0,46$ & 0,33 & 0,10 & 0,26 & 0,84 & 0,42 & 0,88 \\
\hline 14 & Germany & 0,11 & $-0,38$ & $-0,14$ & 0,03 & 0,44 & 0,59 & $-0,48$ & 0,81 \\
\hline 15 & Greece & 0,78 & 0,26 & $-0,61$ & $-0,49$ & $-0,12$ & 0,24 & $-0,13$ & 0,73 \\
\hline 16 & Hungary & 0,30 & $-0,55$ & 0,27 & 0,38 & 0,82 & $-0,28$ & $-0,22$ & 0,79 \\
\hline 17 & Ireland & $\mathrm{H} / \mathrm{A}$ & $-0,12$ & 0,23 & 0,64 & 0,19 & 0,06 & 0,50 & 0,86 \\
\hline 18 & Italy & 0,87 & 0,29 & $-0,22$ & $-0,31$ & 0,20 & 0,64 & 0,02 & 0,62 \\
\hline 19 & Japan & 0,58 & $-0,43$ & $-0,31$ & $-0,58$ & $-0,16$ & $-0,52$ & $-0,27$ & 0,41 \\
\hline 20 & Republic of Korea & 0,69 & $-0,34$ & $-0,01$ & 0,10 & $-0,65$ & $-0,74$ & 0,21 & $-0,54$ \\
\hline 21 & Lithuania & 0,46 & $-0,12$ & 0,30 & 0,34 & 0,54 & 0,76 & $-0,58$ & 0,93 \\
\hline 22 & Luxembourg & $-0,67$ & $-0,18$ & $-0,64$ & $-0,59$ & $-0,40$ & $-0,69$ & 0,17 & 0,66 \\
\hline 23 & Poland & 0,49 & $-0,06$ & 0,49 & 0,39 & 0,65 & 0,75 & $-0,17$ & 0,90 \\
\hline 24 & Portugal & 0,36 & $-0,37$ & 0,21 & 0,34 & 0,48 & 0,40 & 0,25 & 0,79 \\
\hline 25 & Moldova & $-0,01$ & $-0,36$ & 0,19 & $-0,47$ & 0,64 & 0,70 & $-0,46$ & $-0,59$ \\
\hline 26 & Romania & 0,87 & 0,02 & 0,15 & $-0,08$ & 0,78 & 0,32 & $-0,59$ & 0,77 \\
\hline 27 & The Russian Federation & 0,35 & $-0,15$ & 0,28 & $-0,45$ & 0,52 & 0,68 & $-0,19$ & $-0,79$ \\
\hline 28 & United Kingdom & 0,11 & 0,16 & 0,35 & $-0,35$ & 0,55 & 0,13 & $-0,37$ & 0,86 \\
\hline
\end{tabular}

Source: developed by the authors on the basis of World Bank; UNCTAD

on the level of unemployment (it is decreasing). This is logical, after all, the larger volumes of orders from foreign partners are, then more productive capacities of the country are involved and the more workers are required to service the industries. However, there are also some countries that are negatively affected: Albania, Australia, Austria, Azerbaijan, Belarus, Bolivia, Bosnia and Herzegovina, China, Cyprus, France, Honduras, Iceland, Ireland, Lebanon, Malaysia, Morocco, Portugal, Switzerland, and United Kingdom. What's interesting is that for developed countries, the influence is not significant, while for developing countries is noted significant interconnection. The fact that the increase in exports of contract manufacturing services has a positive effect on the unemployment rate may indicate that a significant part of this sector experiences shadow (hidden) employment. The most significant negative impact on the unemployment rate is discovered for the following countries: Bulgaria, Capo Verde, Croatia, Czech Republic, Estonia, Fiji, Finland, Georgia, Italy, Latvia, Lithuania, Luxembourg, Romania, and Macedonia.

Investigating the correlation between the export of contract manufacturing services and FDI inflows, it has been found that both contractual relations and direct foreign investment can be considered as alternatives (in the case of negative interconnection) and complement each other (in the case of positive interconnection). In the first case, with the increase of contractual manufacturing export, the FDI inflows are decreasing; these countries include: Armenia, Austria, Belgium, Belize, Bosnia and Herzegovina, Bulgaria, China, Croatia, Czech Republic, Estonia, Germany, Hungary, Lebanon, Lithuania, Moldova, Romania, Slovakia, and Ukraine.

Countries, where contract manufacturing and foreign investment complement each other, include Albania, Azerbaijan, Bangladesh, Macao, Costa Rica, Georgia, Honduras, Ireland, Malaysia, and Nicaragua. It is worth noting that the use of contract formats can be a preamble to more serious cooperation in the form of foreign investment, the creation of joint ventures and other types of cooperation with a foreign investor.

Taking into account the export of labour-intensive and resource-intensive production, we see that for countries such as Albania, Armenia, Azerbaijan, Belize, Bosnia and Herzegovina, Bulgaria, Croatia, Cyprus, Czech Republic, El Salvador, Georgia, Honduras, 
Hungary, Ireland, Paraguay, Poland, an increase in the export of production under contract leads to an increase in the above indicator. This testifies to the fact that the contractual relations use has been found in industries and spheres of activity, in which labour-intensive products are produced, which does not require specific knowledge and skills and does not require high-capacity or even average production capacity. Typically, the intensive use of contract manufacturing under the order of non-resident companies in such industries is "frizzing" the country in low-tech processes and links in the global value-added chains.

On the contrary, if an increase in the export of production under contract creates an increase in the export of high-tech products, this indicates that contract relations are used in industries with specific competencies where highly qualified workers are needed and where greater value added is created. Countries with this status include: Australia, Austria, Azerbaijan, Bangladesh, Belgium, Bolivia, Bosnia and Herzegovina, Bulgaria, Macao, Croatia, Cyprus, Czech Republic, Dominican Republic, Estonia, Fiji, France, Georgia, Germany, Honduras, Latvia, Lithuania, Paraguay, Poland, Moldova, Slovakia, Slovenia, Switzerland, Tajikistan, and Macedonia.

In our view, it is important to assess the impact of contract production on the level of national economies openness, which reflects the degree of their integration into globalization processes. If the government aims to strengthen its participation in international trade or involve national business in the global value-added chains, it can use contractual relations through the complex of institutional levers, including contract production as an instrument for achieving this goal. Table 1 shows that significant exports of contract manufacturing services have a significant positive impact on the openness of the following countries: Armenia, Austria, Bangladesh, Belgium, Bulgaria, China, Croatia, Cyprus, Czech Republic, Denmark, Estonia, France, Georgia, Germany, Greece, Hungary, Iceland, Ireland, Italy, Japan, Latvia, Lithuania, Luxembourg, Poland, Portugal, Moldova, Serbia, Slovakia, Slovenia, and Tajikistan.

\section{Description of results mentioned in Table 2}

Another interesting observation is that in the majority of the sample there are developed countries and member countries of the G7, which is confirmed by the fact that the customers are advanced economies. However, there is a negative trend for such countries: by off-shoring, certain processes they generate unemployment in their country. Such a situation is applicable to: Austria, China, Finland, France, Greece, and Italy. In other cases, an increase in the contract manufacturing services import is associated with a decrease in unemployment. This can be explained by the fact that contracting is usually only one stage during the value creation process of an international company, and therefore, the increase in production generates job growth at other stages, such as $\mathrm{R} \& \mathrm{D}$, design, marketing, finance, logistics, and others.

For almost all researched countries, the import of contract manufacturing services has a positive impact on the GDP per capita, as evidence of the fact that the main value added falls on the territory of the customer's country, usually the jurisdictions of the TNCs. Also, in most cases, the import of contract manufacturing services positively affects the openness of the economy. For some countries, such as China, Macao (China), Finland, Korea, Moldova, and the Russian Federation, there is a negative correlation between indicators.

At the same time, UNCTAD experts point out that around 18-21 million employees worldwide are officially employed on the contract base in selected industries and value-added chain segments. Most jobs are created through contract manufacturing, outsourcing services, and franchising. About $80 \%$ of jobs created through contractual forms of international business are in emerging and transition economies; especially in contract manufacturing and, to a lesser extent, outsourcing services. In addition, significant indirect impact on employment also affects other types of contractual relations, including contract farming. The jobs created are skilled and unskilled, depending on sector factors (UNCTAD, 2011).

The impact of contract manufacturing on employment in low-tech industries such as apparel and footwear is important for developing countries. Most major brand companies, such as Nike, Adidas, H\&M, Gap, Puma, and Hugo Boss use a large quantity of contract manufacturers based in different developing countries to produce their branded products. For example, all Nike shoes are manufactured by subcontractors outside the United States - about 600 plants in 33 countries, including Argentina, Brazil, Cambodia, China, El Salvador, India, Indonesia, Mexico, Sri Lanka, Thailand, Turkey, and Vietnam, which involves more than 800,000 employees. Similarly, Puma has concluded production agreements with approximately 350 factories, most of which are located in developing countries, which employ 300,000 workers.

Contract farming creates a large number of workplaces for small farmers; its implications for employment and poverty reduction are usually considered positively. The total number of contracting farmers is uncertain; however, individual projects may have several hundreds of thousands of farmer participants at the same time. For example, PTP Group, a joint venture between Asia Timber Products (Singapore) and the local government in Leshan, China, involves 400,000 forest workers in the production of woodfibre boards. Similarly, Nestlé (Switzerland) employs more than 550,000 farmers worldwide, supplying them with products for their food and drink (OECD, 2013). In Mozambique, around 400,000 contractor farmers are involved in global production networks. On a smaller 
scale but, nevertheless, significant for the countries and the segment of global production networks, CocaCola/SABMiller employed 3,741 people in Zambia and 4,244 in El Salvador in 2008, mainly on contractual arrangements (Gereffi, 2011).

The direct impact of contract production under the order of non-resident companies on the localization of value added may be significant; at the same time, indirect effects are differentiated of the contractual relationships' variety, the structure of the global production network of TNCs and the capacity of the local firms used. According to UNCTAD estimates, the creation of local value added of contract manufacturing and other formats of international contractual relations ranges from 400-500 billion USD annually. The largest (of this amount) influence have contract manufacturing and outsourcing services, they account about 200 billion USD. Transboundary franchising accounts for roughly 150 billion USD of value-added worldwide. Although the global value added of contractual relations reflects less than $1 \%$ of world GDP, in some developing countries it represents a significant share of economic activity.

Measuring macroeconomic effects from the development of international contractual relations as a modern strategy for the external expansion of TNCs and the countries they present, does not allow fully assessing the magnitude of a range of socio-cultural and political problems and opportunities arising from its development. In particular, this applies to a large number of host-countries belonging to a group of developing countries. The matter concerns indirect external influences such as changing patterns of consumption and cultural values. Thus, the implementation of international franchising in the national environment can influence socio-cultural norms, contributing to increased consumption, increased use of imported resources, as well as the development and strengthening of commercial values and standards (Rykova, 2011). In this context, although there are many economic benefits that arise from the expansion of local business on the basis of international franchising, international practice also reveals the appearance of institutional conflicts due to the conflict between the elements of "modernization" that involves the implementation of contractual relations, as well as components of traditional identity.

\section{Conclusions}

The study leads to the following generalizations: - the intensification of competition in international markets and the increase of the institutional, political, and economic risks associated with the investment of TNCs lead to the hybridization and the complexity of their external expansion forms, in particular, in the case of the non-linear forms of business development by the international contractual relations; - the latest trend in the transformation of the production networks of TNCs architectonics is the formation of multi-level networks operating through complex coordination mechanisms between suppliers and different management modes: from direct ownership to contractual relationships and trade; - taking into account the multidimensional nature of international contractual relations, they can be identified both from the positions of microeconomic analysis and from the perspective of macroeconomic aspects; - the assessment of the indirect (socio-economic and innovative) effects of contract manufacturing services of non-resident companies on the macroeconomic indicators of the individual countries development has shown contradictory effect, which is conditioned by the status of the country (exporter or importer), sector specificity, specialization in relevant business processes or global production network links.

Prospects for further developments in this area are related to a more in-depth analysis of the mechanisms of fiscal optimization of TNCs through various types of international contractual operations (franchising, licensing, contract management) and institutional instruments for counteracting it.

Gratitude. The preparation and writing of the article became possible with the support and funding of the Ministry of Education and Science of Ukraine in the research topic "The Potential of Import Substitution in Ukraine in the Conditions of the Post-Industrial Economy Establishment", which was carried out at the International Economic Relations Department of KNUTE in 2019 (state registration number 0119U100625).

\section{References:}

Altomonte, S., Rungi, A. (2013). Business Groups as Hierarchies of Firms: Determinants of Vertical Integration and Performance. Fondazione Eni Enrico Mattei (FEEM).

Babek, Y. (2015). Evoliutsyia neaktsyonernykh operatsyi TNK [The evolution of non-equity TNC operations]. Visnyk KNU imeni Tarasa Shevchenka. Retrieved from: http://journals.iir.kiev.ua/index.php/ec_n/article/ viewFile/2766/2470

Baldwin, R. (2013). Global supply chains: why they emerged, why they matter and where are they going. Fung Foundation, Temasek Foundation and World Trade Organization, 13-59.

Barrientos, S. (2011). Economic and social upgrading in global production networks: A new paradigm for a changing world. International Labour Review, 150.

Belousov, K. Yu. (2012). Ustoichyvoe razvytye kompanyy i korporatyvnaia ustoichyvost: problemy interpretatsiy [Sustainable development of the company and corporate sustainability: the problems of interpretation]. Problemy sovremennoy ekonomiky, 4(44), 120-123. (in Russian) 
Buckley, P. J., Casson, M. C. (2009). The internalisation theory of the multinational enterprise: A review of the progress of a research agenda after 30 years. Journal of International Business Studies, 40, 1563-1580.

Derevynskyi, D. O. (2011). Analyz kliuchevykh faktorov razvytyia kontseptsyy upravlenyia byznes-protsessamy BPM [Analysis of key factors in the development of the BPM business process management concept]. Sovremennye aspekty ekonomiky, 2, 115-121. (in Russian)

Dinc, S., Erel, I. (2012). Economic Nationalism in Mergers and Acquisitions. Charles A. Dice Center Working Paper. Duhinets, H. V. (2016). Liudskyi kapital v umovakh rozvytku hlobalnykh lantsiuhiv stvorennia vartosti [Human capital in the context of the development of global value chains]. Zbirnyk naukovykh prats Cherkaskoho derzhavnoho tekhnolohichnoho universytetu. Seriia: Ekonomichni nauky, 41(2), 24-30. Retrieved from: http://nbuv.gov.ua/ UJRN/Znpchdtu_2016_41(2) 6 (in Ukrainian)

Gereffi, G., Fernandez-Stark, K., Psilos, P. (2011). Skills for upgrading: Workforce Development and Global Value Chains in Developing Countries. Durham: Center on Globalization, Governance \& Competitiveness, Duke University.

Hodgson, G. M. (1988). Economics and Institutions: A Manifesto for a Modern Institutional Economics. Polity Press and University of Pennsylvania Press.

Kashbrazyev, R. V. (2017). Fynansovye i instytutsyonalnye mekhanizmy obespechenyia mezhdunarodnoi proyzvodstvennoi kooperatsyy [Financial and institutional mechanisms for ensuring international production cooperation]. Moskva. (in Russian)

Mazaraki, A., Melnichenko, S., Duginets, G. et al. (2018). Ukrainian economy growth imperatives: Monograph. Prague: Coretex CZ SE.

Miroudot, S., Lanz, R., Ragoussis, A. (2009). Trade in intermediate goods and services. OECD Trade Policy Working Paper. Retrieved from: http://www.oecd.org/dataoecd/47/14/44437205.pdf

Rohach, O. (2013). Kharakterni rysy rozvytku mizhnarodnoho vyrobnytstva TNK v postkryzovyi period [Characteristic features of the development of international production of TNCs in the post-crisis period]. Aktualni problemy mizhnarodnykh vidnosyn: zb. nauk. prats, 112, 276-280.

Rykova, Yu. V. (2001). Franchaizynh v deiatelnosty otechestvennykh proyzvodytelei [Franchising in the activities of domestic manufacturers]. Marketynh $v$ Rossyy i za rubezhom, 21. (in Russian)

Site of OECD. Interconnected Economies: Benefiting from Global Value Chains. Retrieved from: http://www.oecd.orgjstijindjinterconnected-economies-GVCs-synthesis.pdf

Site of United Nations conference on trade and development. UNCTADSTAT Data center: Services (BPM6): Exports and imports by service-category and by trade-partner. Retrieved from: http://unctadstat.unctad.org/wds/ ReportFolders/reportFolders.aspx

Site of United Nations conference on trade and development. World Investment Report 2011: Non-Equity Modes of International Production and Development. Retrieved from: http://unctad.org/en/pages/PublicationWebflyer. aspx?publicationid $=84$

Site of World Bank Open Data. World development indicators. Retrieved from: http://databank.worldbank.org/ data/home.aspx 